\title{
LA-UR-20-24474
}

Approved for public release; distribution is unlimited.

Title:

LANL Overview Summer 2020

Author(s): $\quad$ Sarrao, John Louis

Intended for: $\quad$ He is filming a video.

Issued: 
Disclaimer:

Los Alamos National Laboratory, an affirmative action/equal opportunity employer, is operated by Triad National Security, LLC for the National Nuclear Security Administration of U.S. Department of Energy under contract 89233218CNA000001. By approving this article, the publisher recognizes that the U.S. Government retains nonexclusive, royalty-free license to publish or reproduce the published form of this contribution, or to allow others to do so, for U.S. Government purposes. Los Alamos National Laboratory requests that the publisher identify this article as work performed under the auspices of the U.S. Department of Energy. Los Alamos National Laboratory strongly supports academic freedom and a researcher's right to publish; as an institution, however, the Laboratory does not endorse the viewpoint of a publication or guarantee its technical correctness. 


\section{Overview \\ Los Alamos National Laboratory}

John Sarrao
Deputy Director
Science, Technology \& Engineering

[LANL Summer Student, 1990]

- Los Alamos

NATIONAL LABORATORY

Summer, 2020 


\section{The Laboratory is a complex, dynamic system of people, facilities, materials, and services}

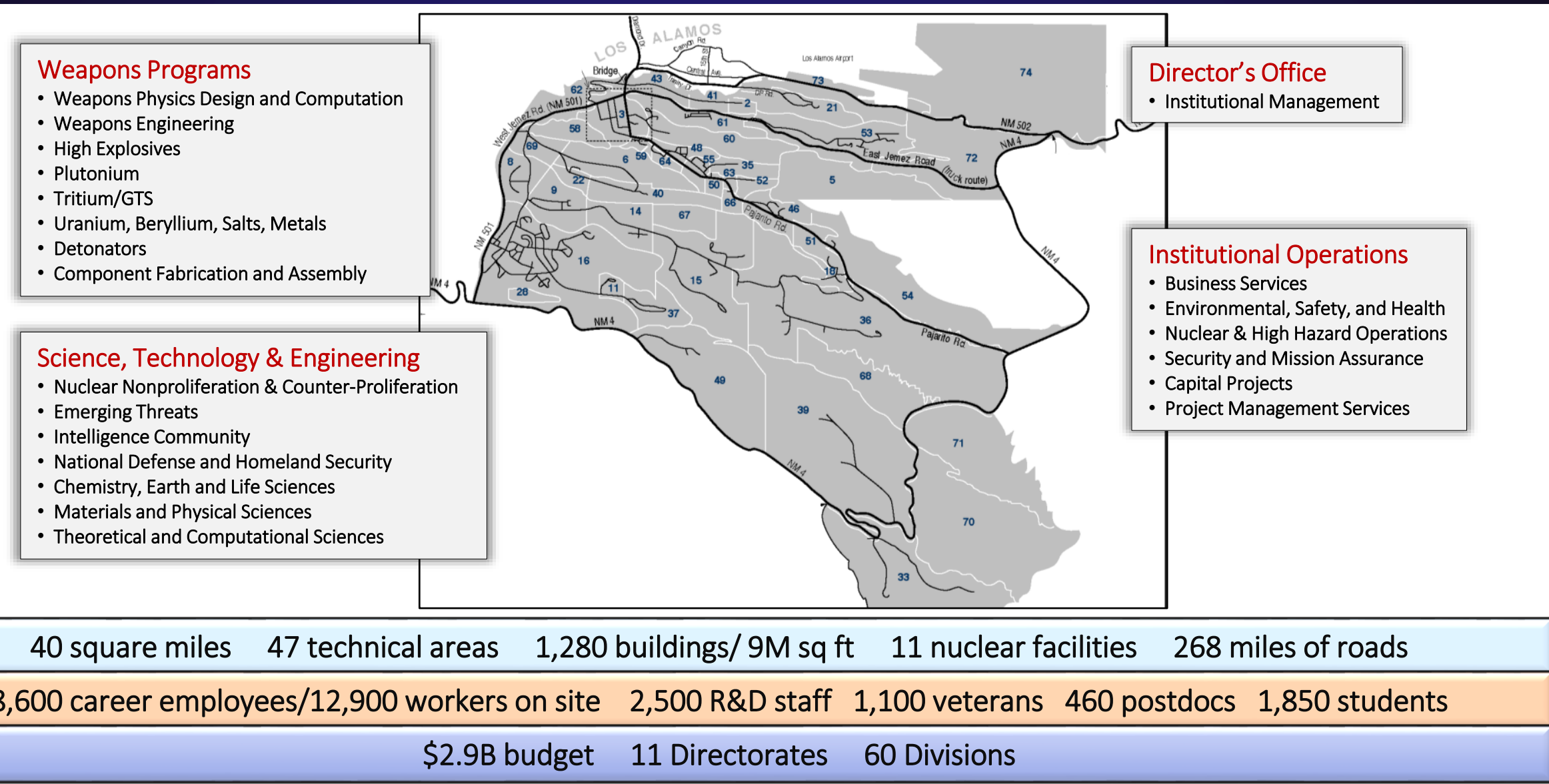




\section{Los Alamos National Laboratory Organizational structure}

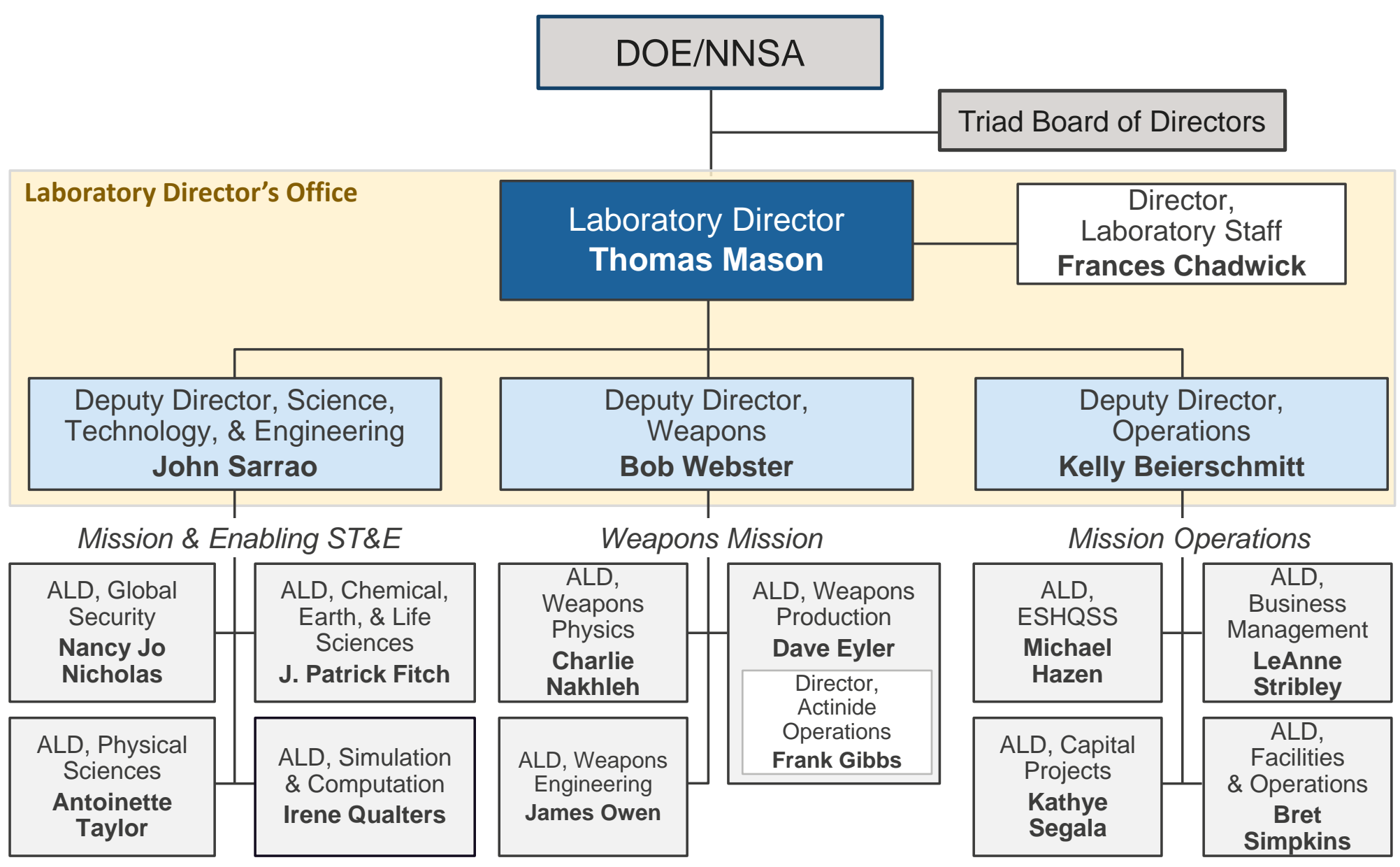




\section{DDSTE organization}

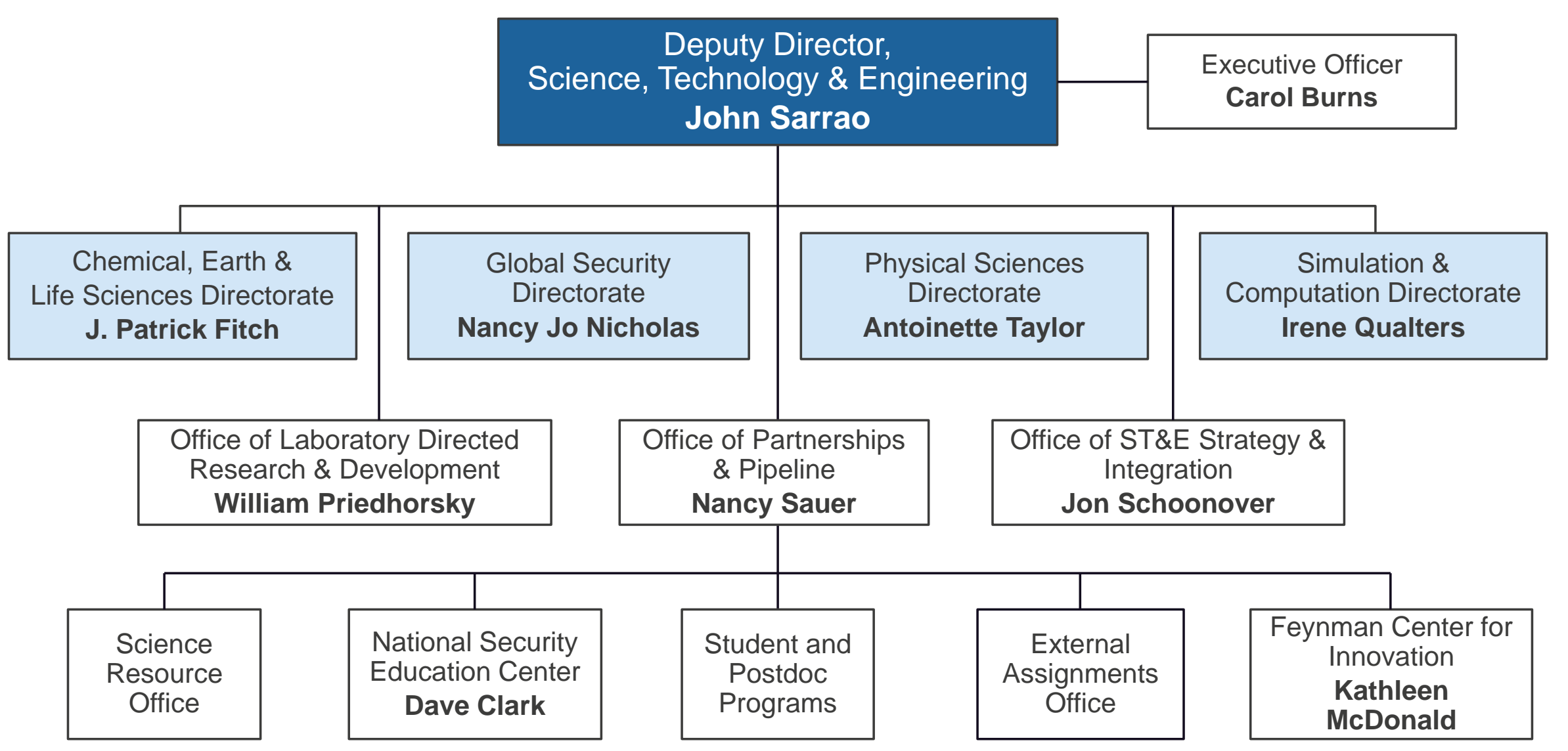




\section{Simultaneous excellence:}

\section{Balance between operations and mission}

Design, produce, and certify current and future nuclear weapons and reduce global nuclear threats
Execute sustained operations that are reliable and responsive to mission needs

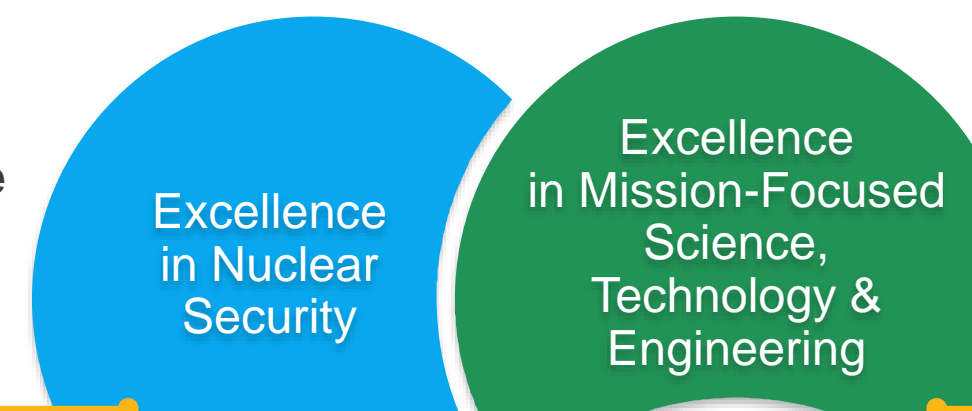

Excellence Science, Technology \& Engineering
Deliver scientific discovery and technical breakthroughs that support DOE \& NNSA missions
Sustain and enhance LANL's partnership with the community across Northern New Mexico

\section{How we do our work is as important as what we do}




\section{Los Alamos' core mission is to ensure the U.S. nuclear deterrent}

- Ensure safety, reliability, and performance of U.S. nuclear stockpile

- Design agency for 4 out of 7 warhead systems constituting the nation's deterrent

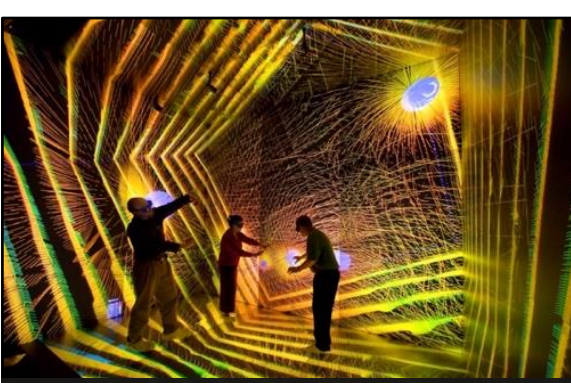

Modeling \& simulation

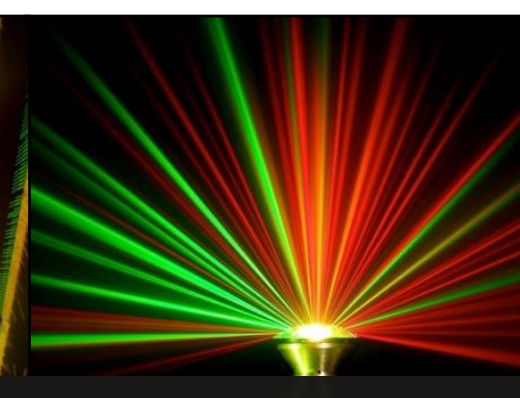

Specialized experiments

- Physics design \& engineering

- Significant \& growing production responsibilities: detonators, heat sources, Pu pits

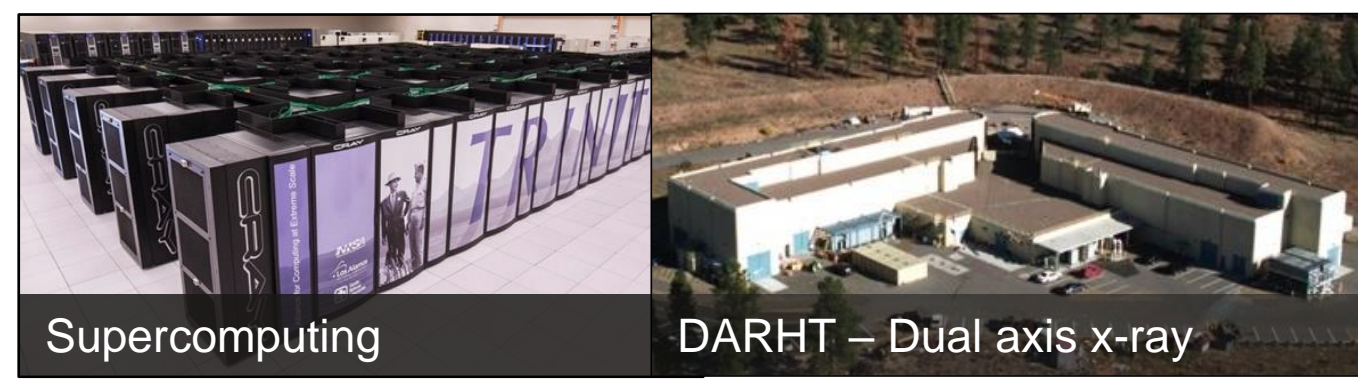

Los Alamos uses scientific assessment, experimentation \& modeling to assess and certify the stockpile, which has aged significantly since it was first developed and since the conclusion of full-scale testing 


\section{Our national security mission is broad and important - and motivates and is enabled by ST\&E discovery}

Ensure the safety, reliability, and performance of the U.S nuclear stockpile

- Physics \& Design

- Engineering

- Production

Preventing and countering efforts of proliferants to acquire, develop or disseminate materials and expertise necessary for nuclear weapons

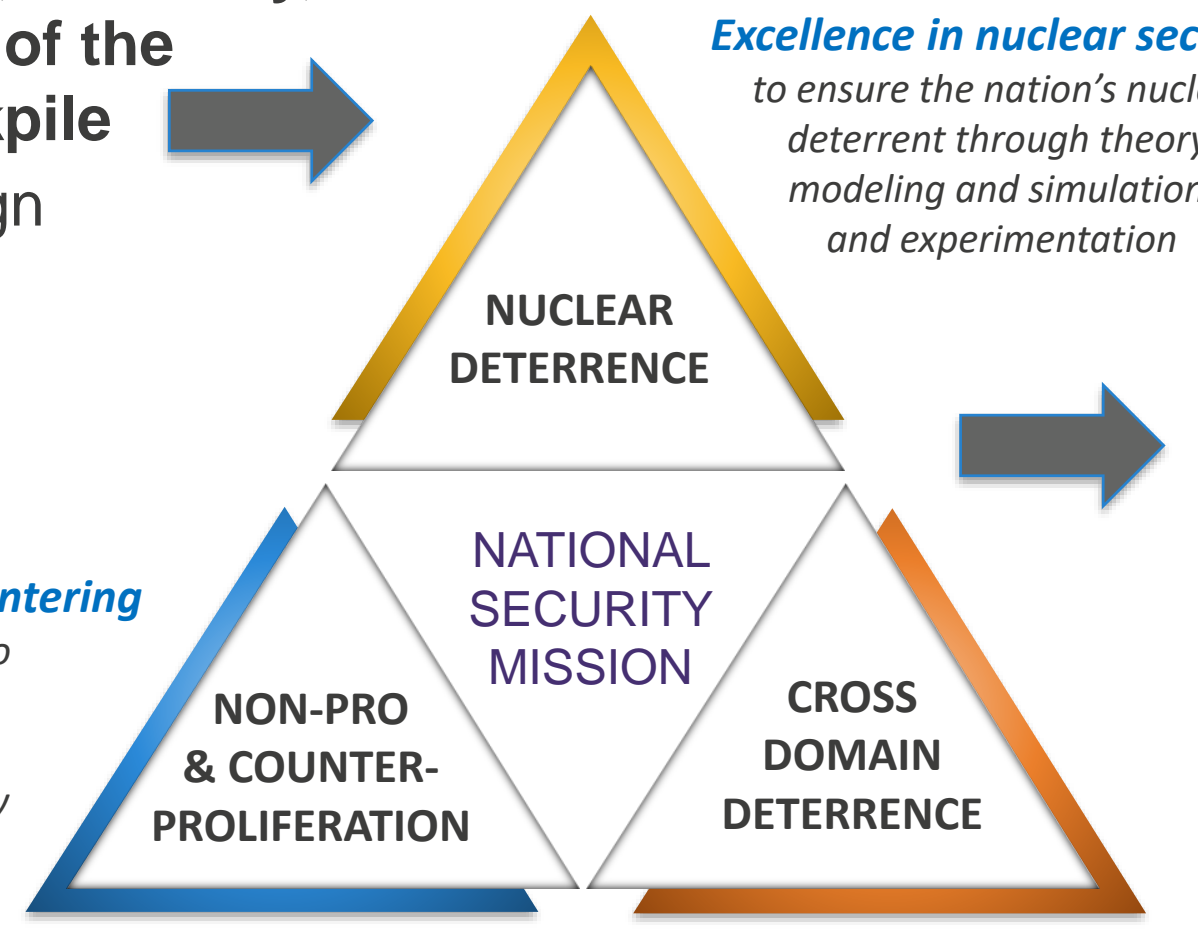

Energy security

- Sustainable Nuclear Energy

- Resilient Materials

- Complexity in Energy Systems

Supporting the DoD, IC, and other national security partners to execute multidomain operations across land, air, sea, space and cyber 


\section{Our capability areas now define six key areas of science, technology \& engineering in which we must lead}

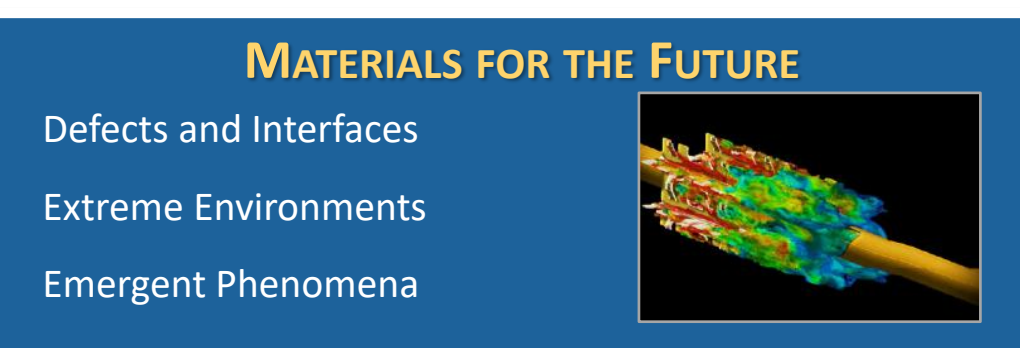

NUCLEAR AND PARTICLE FUTURES High Energy Density Physics \& Fluid Dynamics Nuclear \& Particle Physics, Astrophysics \& Cosmology Applied Nuclear Science \& Engineering Accelerator Science \& Technology

INTEGRATING JNFORIMATION, SCIENCE, AND TECHNOLOGY FOR PREDICTION
Complex Networks
Computational Co-Design
Data Science at Scale

\section{SCIENCE OF SIGNATURES}

Nuclear Detonation

Nuclear Processing, Movement, Weaponization

Natural and Anthropogenic Phenomena

WEAPONS SYSTEMS

Design

Manufacturing

Analysis

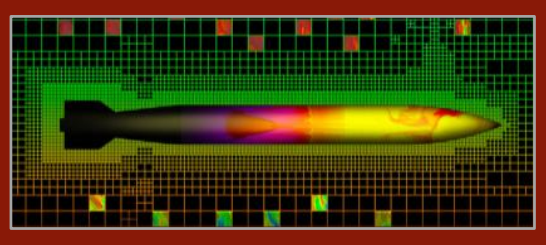

COMPLEX NATURAL AND ENGINEERED SYSTEMS Human-Natural System Interactions: Nuclear

Engineered Systems

Human-Natural System Interactions: Non-Nuclear

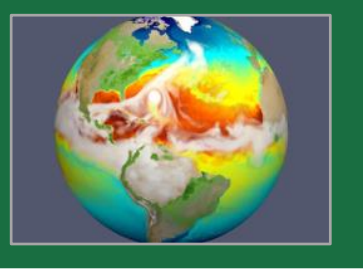




\section{FY20 Lab Agenda}

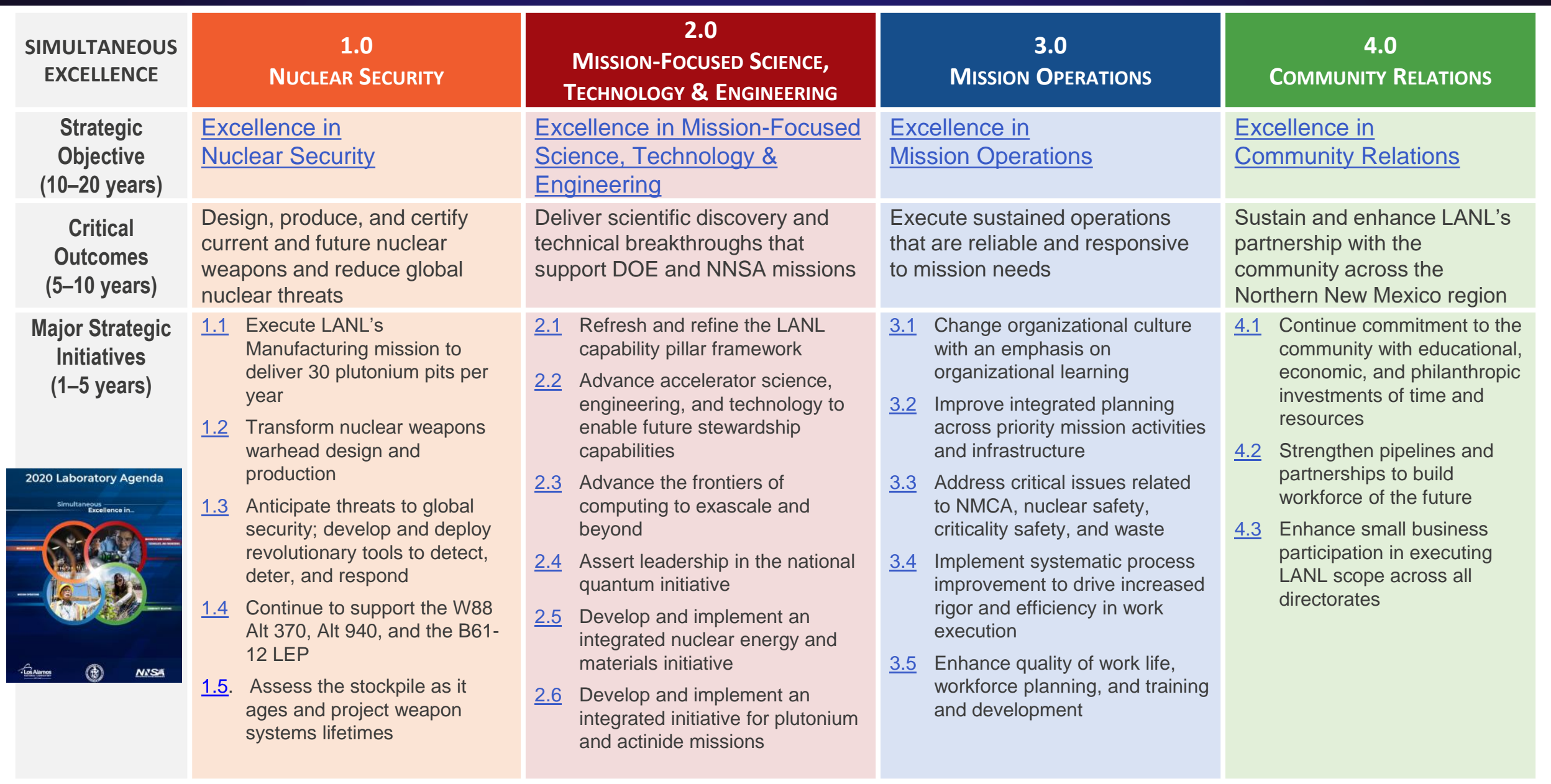




\section{FY20 Lab Agenda}

\begin{tabular}{|c|c|c|}
\hline $\begin{array}{l}\text { SIMULTANEOUS } \\
\text { EXCELLENCE }\end{array}$ & $\begin{array}{c}1.0 \\
\text { NUCLEAR SECURITY }\end{array}$ & $\begin{array}{c}2.0 \\
\text { Mission-Focused SCIENCE, TeCHNOLOGY \& } \\
\text { ENGINEERING }\end{array}$ \\
\hline $\begin{array}{l}\text { Strategic Objective } \\
\text { (10-20 years) }\end{array}$ & Excellence in Nuclear Security & $\begin{array}{l}\text { Excellence in Mission-Focused Science, Technology \& } \\
\text { Engineering }\end{array}$ \\
\hline $\begin{array}{l}\text { Critical Outcomes } \\
\text { (5-10 years) }\end{array}$ & $\begin{array}{l}\text { Design, produce, and certify current and future } \\
\text { nuclear weapons and reduce global nuclear } \\
\text { threats }\end{array}$ & $\begin{array}{l}\text { Deliver scientific discovery and technical } \\
\text { breakthroughs that support DOE and NNSA missions }\end{array}$ \\
\hline \multirow{6}{*}{$\begin{array}{l}\text { Major Strategic } \\
\text { Initiatives } \\
\text { (1-5 years) }\end{array}$} & $\begin{array}{l}1.1 \text { Execute LANL's Manufacturing mission to } \\
\text { deliver } 30 \text { plutonium pits per year }\end{array}$ & $\begin{array}{l}\text { 2.1 Refresh and refine the LANL capability pillar } \\
\text { framework }\end{array}$ \\
\hline & $\begin{array}{l}1.2 \text { Transform nuclear weapons warhead design } \\
\text { and production }\end{array}$ & $\begin{array}{l}\text { 2.2 Advance accelerator science, engineering, and } \\
\text { technology to enable future stewardship }\end{array}$ \\
\hline & \multirow{4}{*}{$\begin{array}{l}1.3 \text { Anticipate threats to global security; develop } \\
\text { and deploy revolutionary tools to detect, deter, } \\
\text { and respond } \\
1.4 \text { Continue to support the W88 Alt } 370 \text {, Alt } 940 \text {, } \\
\text { and the B61-12 LEP } \\
\underline{1.5} \text {. Assess the stockpile as it ages and project } \\
\text { weapon systems lifetimes }\end{array}$} & $\begin{array}{l}\text { capabilities } \\
\text { 2.3 Advance the frontiers of computing to exascale } \\
\text { and beyond }\end{array}$ \\
\hline & & 2.4 Assert leadership in the national quantum initiative \\
\hline & & $\begin{array}{l}2.5 \text { Develop and implement an integrated nuclear } \\
\text { energy and materials initiative }\end{array}$ \\
\hline & & $\begin{array}{l}\text { 2.6 Develop and implement an integrated initiative for } \\
\text { plutonium and actinide missions }\end{array}$ \\
\hline
\end{tabular}


Partnerships \& Pipeline Office (PPO) was formed at transition to enhance our internal coordination and external outreach

\section{Pipeline Mechanisms:}

- Student Programs: Education opportunities for high school, undergraduate, and graduate students

- Postdoctoral Programs: Postdocs contribute to research efforts, enhance our STE capabilities

\section{Partnership Opportunities:}

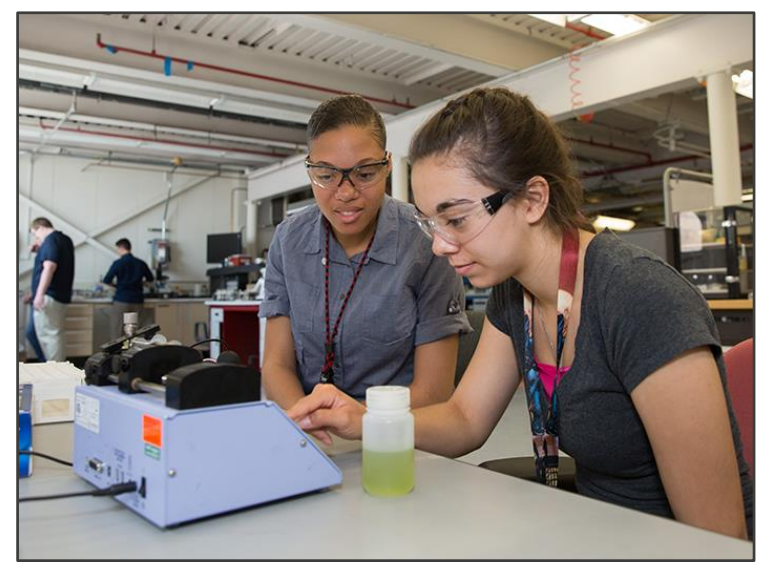

- National Security Education Center Strategic Centers: Scientific centers of excellence with high international visibility that innovate strategic new science and education programs

- New Mexico Consortium Coordination: Creative mechanisms for collaboration with NM research universities through joint appointments and unique facilities

- Feynman Center for Innovation: From "tech transfer"' to innovation asset stewardship with strategy driven through Innovation Asset Strategic Council 


\section{The Laboratory continues to be essential to the nation's security}

\section{Los Alamos delivers national security mission solutions}

- By applying multidisciplinary science, technology \& engineering capabilities, in unique experimental, computational, and nuclear facilities

- With an agile, responsive, and innovative workforce

- Dedicated to addressing complex national security issues and the world's most difficult challenges
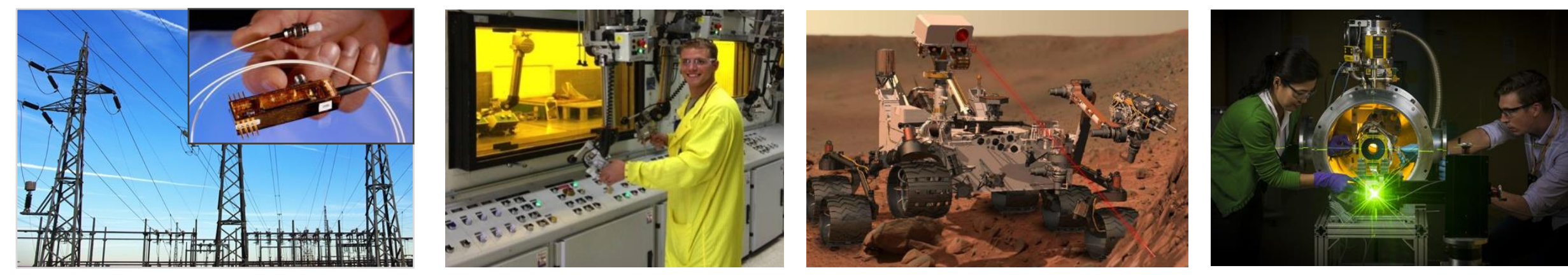


\section{Advice for exploring opportunities (collaborative and employment)}

- Be persistent and don't be shy

- Think broadly

- Very few of us are doing today the job we were hired to do

- ALDs don't bite (and it's their job to engage with you)

- You have a right to expect transparency and consistency in conversion discussions

- Engage early and often

- I'm happy to personally help 